\title{
Genetic characterization of Bhutanese native chickens based on an analysis of Red Junglefowl (Gallus gallus gallus and Gallus gallus spadecieus), domestic Southeast Asian and commercial chicken lines (Gallus gallus domesticus)
}

\author{
Nedup Dorji ${ }^{1,2}$, Monchai Duangjinda ${ }^{1,3,4}$ and Yupin Phasuk ${ }^{1}$ \\ ${ }^{1}$ Department of Animal Science, Faculty of Agriculture, Khon Kaen University, Khon Kaen, Thailand. \\ ${ }^{2}$ Faculty of Animal Husbandry, College of Natural Resources, Royal University of Bhutan, Bhutan. \\ ${ }^{3}$ Center of Excellence on Agricultural Biotechnology, Bangkok, Thailand. \\ ${ }^{4}$ Research and Development Network Center for Animal Breeding, Khon Kaen University, Khon Kaen, \\ Thailand.
}

\begin{abstract}
The genetic diversity of Bhutanese chickens needs to be understood in order to develop a suitable conservation strategy for these birds in Bhutan. In this, work, we used microsatellite markers to examine the genetic diversity of Bhutanese chickens. Four Bhutanese chicken varieties (Black plumage, Frizzle, Naked neck and Red Junglefowllike, corresponding to Yuebjha Narp, Phulom, Khuilay and Seim, respectively), two subspecies of Red Junglefowl (Gallus gallus gallus and Gallus gallus spadecieus), two varieties of Thai native chickens (Pradhu Hang Dam and Chee; Gallus gallus domesticus) representing the Southeast Asian domestic chicken, and two commercial lines (Broiler and Single Comb White Leghorn) were genotyped with 18 microsatellites that included 16 loci recommended by the FAO/ISAG for investigations of genetic variability in chickens. All loci were polymorphic, with the number of alleles ranging from six (MCW0111) to 23 (MCW0183). Substantial genetic variation was observed in all populations, with the Bhutanese native chicken Yuebjha Narp (Black plumage chicken) showing the lowest genetic variability. Despite extensive intrapopulation variation, the genetic differentiation among 10 populations was moderate. A neighbor-joining tree revealed the genetic relationships involved while principal component analysis showed that Bhutanese native chickens should be given priority in conservation efforts because of their genetic distinctiveness. Chee chickens are especially valuable as a reservoir of predomestic diversity, as indicated by their greater genetic variation and their position in the phylogenetic tree.
\end{abstract}

Key words: conservation genetics, genetic comparisons, genetic variability, microsatellites.

Received: September 10, 2011; Accepted: March 26, 2012.

\section{Introduction}

Domestic chickens are believed to have originated in Southeast Asia, with Thai native chickens being regarded as the original domesticated chickens (Hillel et al., 2003). The decrease in the genetic diversity of native chicken populations described in recent genetic studies has raised concern because the unique genotypes and traits of native populations are at risk of being lost, with a consequent threat to a well-established food source (Nassiri et al., 2007). This situation suggests that the management of native chicken genetic resources should be given greater priority.

Send correspondence to Monchai Duangjinda. Research and Development Network Center for Animal Breeding, Department of Animal Science, Faculty of Agriculture, Khon Kaen University, 40002 Khon Kaen, Thailand. E-mail: monchai@kku.ac.th.
Bhutanese native chickens are of socio-cultural and economic importance to the livelihood of many rural populations. For instance, these birds are slaughtered to please local deities, feed guests, and supplement the diet (with eggs and meat) of women during pregnancy and after birth (Nidup et al., 2005). For these reasons, native chickens continue to thrive despite the introduction of several breeds and strains of exotic chickens by the Bhutanese government. Native chickens constitute about $95 \%$ of the chicken population in Bhutan (Nidup and Tshering, 2007). The phenotypic characteristics (Nidup et al., 2008), blood group polymorphism (Yamamoto et al., 2007) and mitochondrial DNA sequences suggest that Bhutanese native chickens are genetically diverse (Nidup et al., 2005). However, they have not been genotyped using microsatellite markers recommended by the Food and Agriculture Organization and International Society for Animal Genetics 
(FAO/ISAG). The genetic diversity of native chickens needs to be thoroughly assessed in order to ensure sustainable poultry production.

According to Nidup et al. (2005), there are 13 strains of native chickens in Bhutan. However, the FAO Domestic Animal Diversity Information System lists only 10 strains. Currently, based on their socio-economic importance and popularity among farmers, four common strains may be tentatively considered to represent the general Bhutanese chicken population. Seim (Red Junglefow-like) is a commonly reared breed that is believed to be an immediate descendent of Red Junglefowl (Nidup et al., 2008) while Yuebjha Narp (Black plumage) is considered to have medicinal values. Khuilay (Naked neck) chickens are generally found in warmer regions of the country and this is consistent with the suggestion that these birds are heattolerant (Yunis and Cahaner, 1999). On the other hand, Phulom (Frizzle) chickens are specifically reared by some castes in southern Bhutan. Previous studies have examined genetic variations in Black plumage (Granevitze et al., 2007) and Naked neck (Nassiri et al., 2007; Pirany et al., 2007) chicken populations in several countries. Some Bhutanese chickens resemble to their ancestor (Red Junglefowl) while others resemble commercial lines.

In the last decade, the investigation of population variations has involved multi-allele markers. In particular, microsatellites have become a powerful tool for studying population genetics because of their unique characteristics, such as random distribution over the genome, codominant inheritance, high mutational rate and high reproducibility (Weigend and Romanov, 2001; Hillel et al., 2003). In this study, we used microsatellites to investigate the genetic variation among Bhutanese native chickens and to assess their genetic relatedness to Red Junglefowl, Thai native chickens and commercial lines. This information should provide a basis for developing effective conservation programs.

\section{Materials and Methods}

\section{Chicken strains and sample sizes}

Two hundred and eighty-eight individuals belonging to four strains of Bhutanese native chickens (Seim, $n=30$; Yuebjha Narp, $n=24$; Khuilay, $n=25$; Phulom, $n=26$ ), two strains of Thai native chickens (Pradhu Hang Dam, $\mathrm{n}=30$; Chee, $\mathrm{n}=32$ ), two subspecies of Red Junglefowl (Gallus gallus gallus, $\mathrm{n}=31$; Gallus gallus spadiceus, $\mathrm{n}=30$ ), and two commercial lines (Broiler, $\mathrm{n}=30$; White Leghorn, $\mathrm{n}=30$ ) were studied (Table 1). The minimum sample size suggested by Tadano et al. (2007) was used in this study. The Mendelgang and Deorali (Bhutan) strains were also sampled because of an expected high genetic variation compared to other strains.

Blood samples $(1.5 \mathrm{~mL})$ were drawn from the ulnar vein into a microtube containing $0.5 \mathrm{M}$ EDTA and DNA was isolated as described in Goodwin et al. (2007). The blood samples from Red Junglefowl were collected at the Department of National Parks, Wildlife and Plant Conservation (DNP), and those from Pradhu Hang Dam and Chee at the Research and Development Network Center for Animal Breeding (Native chicken) and the Department of Livestock Development, respectively; samples from com-

Table 1 -

Characteristics of Bhutanese and Thai native chickens and subspecies of Red Junglefowl used in this study.

\begin{tabular}{|c|c|c|c|c|}
\hline \multirow[t]{2}{*}{ Strains } & \multirow[t]{2}{*}{ Distribution } & \multicolumn{3}{|c|}{ Morphological features } \\
\hline & & Comb type & Plumage & Shank and Beak \\
\hline $\begin{array}{l}\text { Seim (Red } \\
\text { Junglefowl-like) }\end{array}$ & Throughout Bhutan & Rose, pea, single & $\begin{array}{l}\text { Red junglefowl-like, greenish, tailed, sickle-shaped } \\
\text { feathers; male are golden brown, sometimes reddish } \\
\text { brown saddle; female are brownish red with } \\
\text { dark-greenish stripe on each feather. }\end{array}$ & Black, yellowish \\
\hline $\begin{array}{l}\text { Yuebjha Narp } \\
\text { (Black plumage) }\end{array}$ & $\begin{array}{l}\text { Southwestern and western } \\
\text { Bhutan }\end{array}$ & Rose, pea & $\begin{array}{l}\text { Both sexes are entirely black; name derived from mor- } \\
\text { phology. }\end{array}$ & Blackish, slate \\
\hline $\begin{array}{l}\text { Khuilay (Naked } \\
\text { neck) }\end{array}$ & $\begin{array}{l}\text { Southern and southwestern } \\
\text { Bhutan }\end{array}$ & Rose, pea, single & $\begin{array}{l}\text { Generally soft-feather red, diverse plumage } \\
\text { color, e.g., white, partridge; featherless at neck. }\end{array}$ & Yellowish, whitish \\
\hline $\begin{array}{l}\text { Phulom } \\
\text { (Frizzle) }\end{array}$ & $\begin{array}{l}\text { Southwestern and southern } \\
\text { Bhutan }\end{array}$ & Rose, pea & $\begin{array}{l}\text { Feathers face outwards (various colors as in } \\
\text { Seim, black). }\end{array}$ & Yellowish, black \\
\hline $\begin{array}{l}\text { Pradhu Hang } \\
\text { Dam }\end{array}$ & Northeastern Thailand & Pea & Both adults are completely black. & Black \\
\hline Chee & Central Thailand & Pea & Entire plumage is white in adults of both sexes. & Yellowish \\
\hline G. g. gallus & Northeastern Thailand & Single & $\begin{array}{l}\text { Male has yellowish hackles, dark green sickle-shaped } \\
\text { feathers; females are dull brown; white ear lobe. }\end{array}$ & Slate, grey, yellowish \\
\hline G. g. spadiceus & Northern Thailand & Single & $\begin{array}{l}\text { Male has uniform golden yellow cover from neck to } \\
\text { lower back; tail feathers are greenish black with white } \\
\text { patches; females are dark brown with yellowish plum- } \\
\text { age designed for camouflage; red ear lobe. }\end{array}$ & Slate, grey, yellowish \\
\hline
\end{tabular}


mercial lines were collected at private poultry companies in Thailand.

\section{Microsatellite genotyping}

Eighteen microsatellite combinations from the FAO/ISAG list and Nassiri et al. (2007) were used; these microsatellites were also used in the AVIANDIV project (Hillel et al., 2003). Microsatellite loci amplification was done by polymerase chain reaction (PCR) with specific primers and annealing temperatures (Table 2). The electrophoretic bands of the PCR products were scored using a SYNGENE Gel documentation system (Syngene Inc., UK).

\section{Data and statistical analyses}

The alleles were analyzed to determine the mean number of alleles per locus and the observed $\left(\mathrm{H}_{\mathrm{O}}\right)$ and expected $\left(\mathrm{H}_{\mathrm{E}}\right)$ heterozygosities. The Chi-square test was used to assess Hardy-Weinberg equilibrium (HWE). The fixation coefficient of an individual within a subpopulation $\left(\mathrm{F}_{\mathrm{IS}}\right)$ and the fixation coefficient of a subpopulation within the general population $\left(\mathrm{F}_{\mathrm{ST}}\right)$ were estimated using GENEPOP v. 4.0.10 (Raymond and Rousset, 1995; Rousset, 2008). A neighbor-joining method (Saitou and Nei, 1987) in the Numerical Taxonomy System (NTSYSpc) v. 2.10 package was used to construct a phylogenetic tree based on
Nei's unbiased genetic distance (Nei, 1978). Principal component analysis - PCA (SAS, 1998) based on individual Dice genetic distances was used to visualize the genetic relationships and detect geographical clines that were not apparent from the phylogenetic tree. Numerical data were expressed as the mean \pm SD with $\mathrm{p}<0.05$ indicating significance.

\section{Results}

\section{Microsatellite polymorphism and population diversity}

The genetic variability of the microsatellite loci is summarized in Table 2. 255 alleles were detected across 18 loci in ten chicken populations, with a mean number of alleles per locus (MNA $\pm \mathrm{SD}$ ) of $14.17 \pm 4.37$. Locus MCW0183 was highly polymorphic with 23 alleles while MCW0111 had the lowest polymorphism (6 alleles per locus). Averaged over the 18 loci for each population, the $\mathrm{H}_{\mathrm{O}}$ and $\mathrm{H}_{\mathrm{E}}$ ranged from 0.262 (MCW0248) to 0.791 (LEI0094) and 0.669 (MCW0111) to 0.898 (LEI0094), respectively. For all loci, the mean $\mathrm{H}_{\mathrm{E}}$ was higher than the mean $\mathrm{H}_{\mathrm{O}}$ (Table 2), which suggested sampling bias or a possible inbreeding mating system.

Table 3 summarizes the genetic variation across populations. This variation was greatest for Chee $(\mathrm{MNA} \pm \mathrm{SD}$,

Table 2 - Characteristics of the 18 microsatellite markers used in this study and the number of alleles observed at each locus.

\begin{tabular}{|c|c|c|c|c|c|c|c|}
\hline \multirow[t]{2}{*}{ Locus } & \multirow[t]{2}{*}{$\operatorname{Tm}\left({ }^{\circ} \mathrm{C}\right)^{\mathrm{a}}$} & \multirow[t]{2}{*}{ Alleles per locus } & \multicolumn{2}{|c|}{ Heterozygosity } & \multicolumn{3}{|c|}{ F-statistics } \\
\hline & & & Observed & Expected & $\mathrm{F}_{\mathrm{IS}}^{\mathrm{b}}$ & $\mathrm{F}_{\mathrm{ST}}^{\mathrm{c}}$ & $\mathrm{F}_{\mathrm{IT}}^{\mathrm{d}}$ \\
\hline ADL112 & 60 & 15 & 0.620 & 0.790 & 0.344 & 0.050 & 0.371 \\
\hline ADL0147 & 57 & 12 & 0.540 & 0.821 & 0.400 & 0.067 & 0.440 \\
\hline ADL0268 & 60 & 8 & 0.478 & 0.785 & 0.238 & 0.077 & 0.296 \\
\hline LEI0094 & 60 & 21 & 0.791 & 0.898 & 0.152 & 0.067 & 0.209 \\
\hline LEI0166 & 60 & 18 & 0.633 & 0.859 & 0.223 & 0.099 & 0.300 \\
\hline MCW0014 & 60 & 16 & 0.675 & 0.865 & 0.181 & 0.045 & 0.218 \\
\hline MCW0034 & 60 & 16 & 0.739 & 0.879 & -0.227 & 0.062 & -0.151 \\
\hline MCW0037 & 60 & 13 & 0.601 & 0.791 & 0.232 & 0.089 & 0.250 \\
\hline MCW0081 & 60 & 15 & 0.496 & 0.832 & 0.236 & 0.062 & 0.284 \\
\hline MCW0104 & 60 & 18 & 0.363 & 0.797 & 0.668 & 0.171 & 0.725 \\
\hline MCW0111 & 60 & 6 & 0.318 & 0.669 & 0.456 & 0.151 & 0.538 \\
\hline MCW0123 & 60 & 12 & 0.487 & 0.802 & 0.428 & 0.113 & 0.493 \\
\hline MCW0183 & 60 & 23 & 0.307 & 0.867 & 0.624 & 0.072 & 0.651 \\
\hline MCW222 & 60 & 15 & 0.535 & 0.846 & 0.578 & 0.082 & 0.612 \\
\hline MCW0248 & 62 & 15 & 0.262 & 0.814 & 0.857 & 0.039 & 0.863 \\
\hline MCW295 & 60 & 9 & 0.377 & 0.763 & 0.572 & 0.049 & 0.584 \\
\hline Mean \pm SD & - & $14.17 \pm 0.93$ & $0.508 \pm 0.150$ & $0.814 \pm 0.053$ & $0.363 \pm 0.247$ & $0.084 \pm 0.037$ & $0.414 \pm 0.233$ \\
\hline
\end{tabular}

${ }^{a}$ Annealing temperature; ${ }^{b}$ fixation coefficient of an individual within a subpopulation; ${ }^{c}$ fixation coefficient of a subpopulation within the general population; ${ }^{\mathrm{d}}$ fixation coefficient of an individual within the general population. 
Table 3 - Genetic variability estimates for 18 microsatellite loci in ten chicken populations.

\begin{tabular}{|c|c|c|c|c|}
\hline \multirow[t]{2}{*}{ Population } & \multirow[t]{2}{*}{ Alleles per locus } & \multicolumn{2}{|c|}{ Heterozygosity } & \multirow[t]{2}{*}{$\mathrm{dHWE}^{\mathrm{b}}$} \\
\hline & & Observed & Expected & \\
\hline Gallus gallus spadiceus & $9.28 \pm 0.66$ & $0.47 \pm 0.06$ & $0.81 \pm 0.02$ & 3 \\
\hline Gallus gallus gallus & $9.50 \pm 0.59$ & $0.52 \pm 0.06$ & $0.82 \pm 0.01$ & 2 \\
\hline Seim (Red Junglefowl-like) & $9.33 \pm 0.72$ & $0.51 \pm 0.06$ & $0.82 \pm 0.01$ & 0 \\
\hline Yuebjha Narp (Black plumage) & $7.94 \pm 0.40$ & $0.44 \pm 0.05$ & $0.79 \pm 0.02$ & 0 \\
\hline Khuilay (Naked neck) & $9.50 \pm 0.68$ & $0.49 \pm 0.05$ & $0.83 \pm 0.02$ & 2 \\
\hline Phulom (Frizzle) & $8.50 \pm 0.57$ & $0.55 \pm 0.04$ & $0.81 \pm 0.01$ & 0 \\
\hline Pradhu Hang Dam (Black chicken) & $9.78 \pm 0.69$ & $0.59 \pm 0.06$ & $0.83 \pm 0.02$ & 0 \\
\hline Chee (White chicken) & $10.83 \pm 0.85$ & $0.58 \pm 0.04$ & $0.84 \pm 0.02$ & 2 \\
\hline Broiler & $9.28 \pm 0.77$ & $0.49 \pm 0.06$ & $0.82 \pm 0.02$ & 8 \\
\hline White Leghorn & $8.67 \pm 0.82$ & $0.45 \pm 0.06$ & $0.78 \pm 0.02$ & 2 \\
\hline
\end{tabular}

The values are the mean \pm SD. ${ }^{a}$ Mean number of alleles per locus; ${ }^{b}$ number of loci deviating from Hardy-Weinberg equilibrium.

$\left.10.83 \pm 0.85 ; \mathrm{H}_{\mathrm{O}}, 0.58 \pm 0.04 ; \mathrm{H}_{\mathrm{E}}, 0.84 \pm 0.02\right)$ and Khuilay $\left(\mathrm{MNA} \pm \mathrm{SD}, 9.50 \pm 0.68 ; \mathrm{H}_{\mathrm{O}}, 0.49 \pm 0.04 ; \mathrm{H}_{\mathrm{E}}, 0.83 \pm 0.02\right.$ ) varieties. In contrast, Phulom (MNA $\pm \mathrm{SD}, 8.50 \pm 0.57 ; \mathrm{H}_{\mathrm{O}}$, $\left.0.55 \pm 0.04 ; \mathrm{H}_{\mathrm{E}}, 0.81 \pm 0.01\right)$ and Yuebjha Narp (MNA \pm $\mathrm{SD}, 7.94 \pm 0.40 ; \mathrm{H}_{\mathrm{O}}, 0.44 \pm 0.05 ; \mathrm{H}_{\mathrm{E}}, 0.79 \pm 0.02$ ) varieties showed the lowest genetic variation compared to the commercial lines.

The Wright fixation indices for $\mathrm{F}_{\mathrm{IS}}$ ranged from -0.227 (MCW0034) to 0.857 (MCW0248), $\mathrm{F}_{\mathrm{ST}}$ ranged from 0.039 (MCW0248) to 0.171 (MCW0104), and $\mathrm{F}_{\mathrm{IT}}$ ranged from -0.151 (MCW0034) to 0.863 (MCW0248), with means of $0.363 \pm 0.247,0.084 \pm 0.037$ and $0.414 \pm 0.233$, respectively (Table 2 ). A high positive $F_{I S}$ indicated a high degree of observed homozygosity (MCW0248) while there was excessive heterozygosity at locus MCW0034, as indicated by the negative $\mathrm{F}_{\text {IS }}$ value. Significant deviations from HWE $(p<0.5)$ were observed across 10 populations at locus MCW0295. High selection pressure resulted in seven loci that deviated from HWE in the Broiler strain (ADL112, ADL0268, ADL0372, MCW0037, MCW0069, MCW0111 and MCW0123). Deviation of HWE was also found in Red Junglefowl (MCW0111), Chee (ADL112) and Khuilay and White Leghorn (MCW0248).

\section{Genetic relationship and phylogenetic tress}

Table 4 shows the dissimilarity matrices between pairs of populations. A neighbor-joining tree based on Nei's unbiased genetic distance matrices revealed that Khuilay (Bhutanese naked neck) was most closely related to Pradhu Hang Dam (Thai native black). The other three Bhutanese strains, Seim (Red Junglefowl-like), Yuebjha Narp (Black plumage) and Phulom (Frizzle), were in a separate group with a node connected to Pradhu Hang Dam. These findings indicated that Bhutanese native chickens should be classified as being genetically close to Southeast Asian domestic chickens; they also showed that Bhutanese

Table 4 - Genetic distances estimated for 10 chicken populations based on allele frequencies.

\begin{tabular}{lcccccccccc}
\hline & GS & GG & SM & YN & KL & PL & PD & CH & BR & WH \\
\hline GS & 0.000 & & & & & & & & & \\
GG & 0.270 & 0.000 & & & & & & & & \\
SM & 0.443 & 0.382 & 0.000 & & & & & & & \\
YN & 0.515 & 0.344 & 0.418 & 0.000 & & & & & & \\
KL & 0.319 & 0.272 & 0.326 & 0.391 & 0.000 & & & & & \\
PL & 0.370 & 0.470 & 0.350 & 0.393 & 0.394 & 0.000 & & & & \\
PD & 0.245 & 0.283 & 0.346 & 0.357 & 0.204 & 0.401 & 0.000 & & & \\
CH & 0.241 & 0.237 & 0.433 & 0.521 & 0.392 & 0.559 & 0.382 & 0.000 & & \\
BR & 0.233 & 0.283 & 0.381 & 0.447 & 0.267 & 0.439 & 0.203 & 0.279 & 0.000 & \\
WH & 0.390 & 0.199 & 0.413 & 0.483 & 0.296 & 0.465 & 0.344 & 0.297 & 0.372 & 0.000 \\
\hline
\end{tabular}

BR, Broiler; CH, Chee; GG, Gallus gallus gallus; GS, Gallus gallus spadiceus; KL, Khuilay; PD, Pradhu Hang Dam; PL, Phulom; SM, Seim; WH, White Leghorn; YN, Yuebjha Narp. 
native chickens and Thai native chickens ( $G . g$. domesticus) were related to G. g. spadiceus, the red earlobe Red Junglefowl (Figure 1). The relatedness of Khuilay and Pradhu Hang Dam and the separate genetic group formed by the other Bhutanese native chickens were confirmed in the PCA plot. This plot also showed that commercial broilers and the developing line White Leghorn were related to G. g. gallus, the white earlobe Red Junglefowl (Figure 2).

\section{Discussion}

\section{Microsatellite allele diversity and population diversity}

The results of this study indicate that the selected loci were reliable and informative because more than four alleles per locus were examined (Nassiri et al., 2007, 2009). Correspondingly, the estimated genetic distances were precise because the standard error was likely to be low (Nassiri et al., 2007). The $\mathrm{H}_{\mathrm{E}}$ for all loci was $>0.50$ and supported the effectiveness of the selected loci.

The MNA per locus calculated for 10 chicken populations was $14.17 \pm 0.93$ and was similar to the value of
$14.00 \pm 1.69$ recorded in 20 chicken breeds based on 14 markers shared with our study (Rosenberg et al., 2001). In contrast, our value was greater than the $10.00 \pm 1.12$ reported for 52 chicken populations with 12 shared markers from a set of 22 markers (Hillel et al., 2003), $10.11 \pm 0.59$ reported for six South African local chicken lines based on nine shared markers (van Marle-Köster et al., 2008) and $10.33 \pm 4.33$ reported for six Indian chicken populations based on three markers shared with our study (Pirany et al., 2007). Population-specific alleles and/or allele scoring bias (allele dropout, null alleles) could explain these discrepancies in the number of alleles/locus (Nassiri et al., 2007).

Although genetic analyses can reveal the extent of biodiversity in chicken breeds (Nassiri et al., 2007; Semik and Krawczyk, 2011) additional information on specific adaptations, distinct phenotypes, performance level, demography (including effective population size, and geographical distribution), and descriptive databases are required for adequate assessment of each breed when deciding on conservation and breeding programs (Groeneveld et al., 2010).

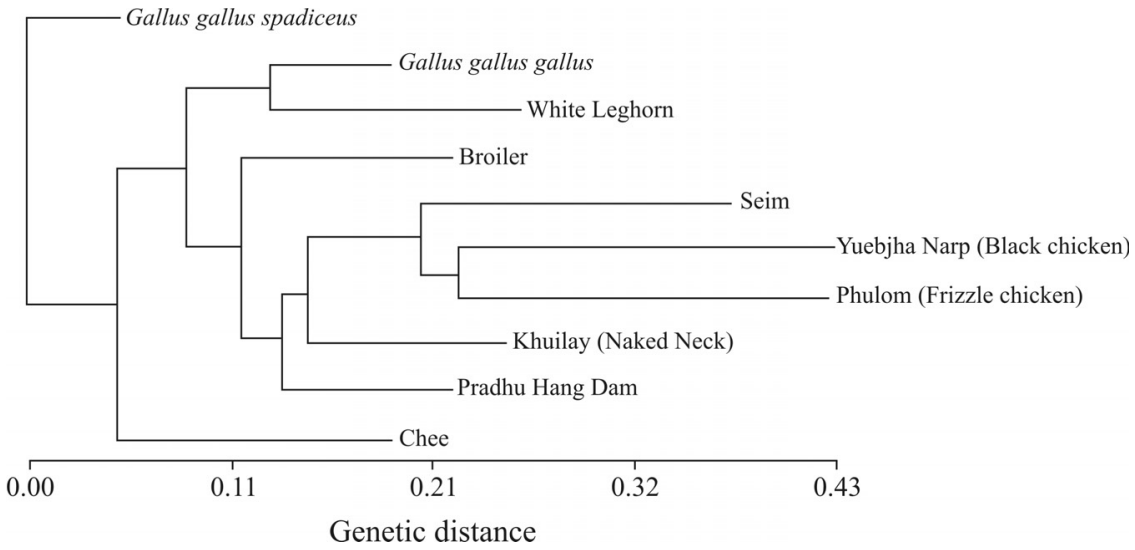

Figure 1 - A phylogenetic tree based on Nei's genetic distance DA 309 (Nei, 1978) for ten chicken populations.

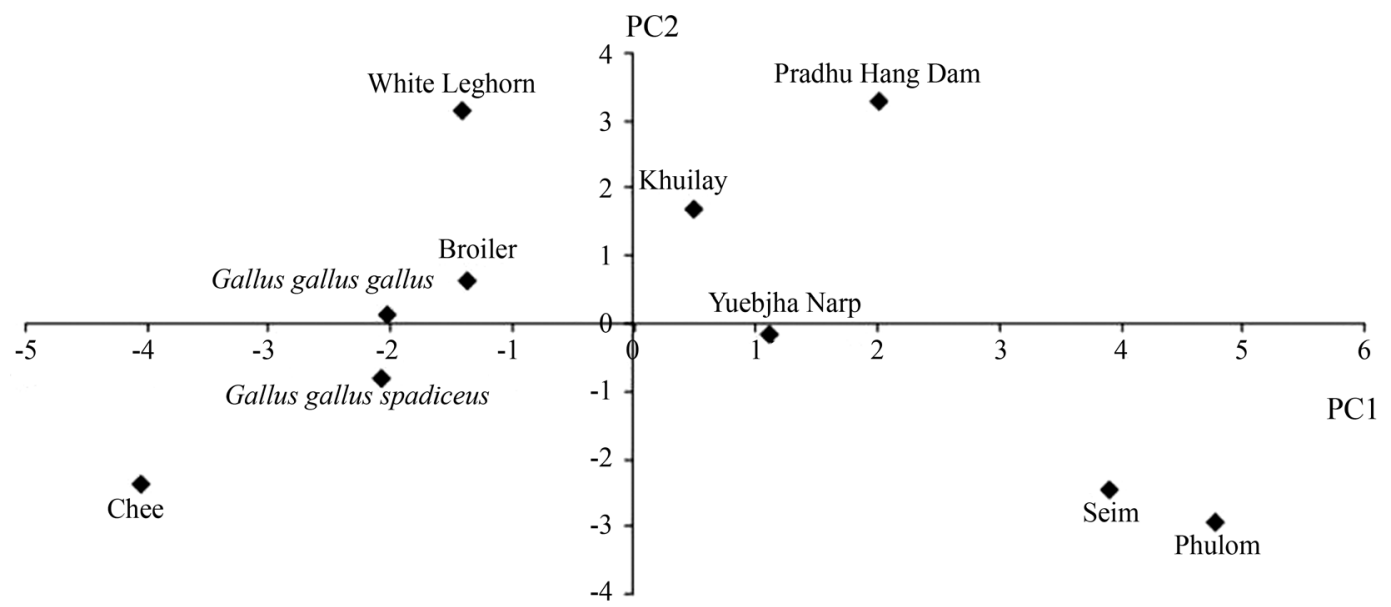

Figure 2 - Principal components plot of averaged first (PC1) and second (PC2) principal component scores based on Dice's coefficient (a similarity coefficient that counts the percentage of shared bands between two individuals) for ten chicken populations. 
The high number of alleles at various loci and the fairly high $\mathrm{F}_{\mathrm{IS}}$ values may partly reflect the influence of environmental factors and geographical barriers. Although the mean $\mathrm{F}_{\mathrm{IS}}$ value was high, there was no significant deviation from HWE in native chickens and Junglefowl chickens. On the other hand, eight loci in Broilers and two in White Leghorn deviated from HWE indicating that decades of intensive selection for morphology and production in commercial populations had resulted in genetic subdivision. Some of the loci identified here may be associated with genes that were lost through genetic drift; this could explain why some loci showed strong genetic differentiation while others showed only slight drift. However, the mean $\mathrm{F}_{\mathrm{ST}}$ value indicated that subpopulation division was moderate, with $8.4 \%$ of the total genetic variation being caused by interpopulation differences while $91.6 \%$ corresponded to intrapopulation differences.

Comparable population variations were observed for Seim and Khuilay in relation to the original and ancestor fowl populations. Seim chickens are commonly reared by Bhutanese farmers whereas the Khuilay variety has a highly diversified plumage color (soft-red, white, black, partridge and speckled), with possible gene flow from Indian Naked neck populations. The major concern here relates to the Yuebjha Narp variety, which showed low variation. Possible reasons for this reduced variability include lower morphological diversity and finite population sizes ( 20-25 individuals per village). As expected, the $\mathrm{H}_{\mathrm{E}}$ across the loci for the two subspecies of Red Junglefowl was greater than for White Leghorn and higher than that reported by Hillel et al. (2003) and Granevitze et al. (2007).

As shown here, the wild progenitor of domestic chickens contains considerable genetic variation, as also reported for Red Junglefowl in northern India (Mukesh et al., 2011). The wild ancestors of major livestock species are important reservoirs of genetic diversity reservoirs but are either extinct or low in numbers (Hanotte and Jianlin, 2005). Consequently, there is a need for a concerted effort to conserve the putative wild ancestors of present-day chickens, particularly because of the increasing habitat loss and fragmentation, as well as poaching, that threaten the wild varieties with extinction. In contrast, commercial lines have been developed from only a few breeds and therefore have a less varied genetic background, i.e., they have less genetic variation than native and Junglefowl populations. Interestingly, the genetic variation seen here was similar to that reported elsewhere (Pirany et al., 2007).

\section{Genetic relationship and phylogenetic trees}

The neighbor-joining (NJ) tree constructed from microsatellite data showed that the two Red Junglefowl subspecies, Gallus gallus gallus and Gallus gallus spadiceus, belonged to different subpopulations. The relatedness of Bhutanese Khuilay (Naked neck) and Thai Pradhu Hang Dam revealed the importance of genetic background in determining heat tolerance. Several reports have demonstrated an association between heat tolerance in Naked neck chickens (Merat, 1986; Yunis and Cahaner 1999; Patra et al., 2002) and the occurrence of heat shock protein 70 (HSP70; Mazzi et al., 2003; Duangdeun, C., 2008, MSc thesis, Khon Kaen University, Thailand). In addition, the highest frequency $(\sim 50 \%)$ of the HSP70 genotype associated with heat tolerance was found in Pradhu Hang Dam (Tunim et al., 2010). The phylogenetic tree showed that Khuilay and Broiler chickens were sufficiently genetically similar to suggest that Khuilay chickens may be suitable for meat production, with the advantage that they are heat tolerant. The NJ tree and PCA plot confirmed that Bhutanese Seim (Red junglefowl-like), Yuebjha Narp (Black plumage), and Phulom (Frizzle) varieties were distinguishable from another chicken strains; this distinction highlights the importance of genetic diversity among Bhutanese native chickens. The Thai Chee breed may be particularly valuable as a source of genetic variability because it is close to the root of the phylogenetic tree.

The PCA plot provided useful information when the NJ method could not differentiate among closely related chicken populations. This plot showed that three of the Bhutanese native varieties formed a group that fell in a different quadrant from Thai native chickens (G. $g$. domesticus), Red Junglefowl (G. gallus) and commercial lines (G. g. domesticus). This divergence may reflect environmental adaptation and breeding history (mating system) that affected the genetics of Bhutanese chickens.

In conclusion, this preliminary study of four Bhutanese native chicken varieties based on 18 microsatellite loci clearly demonstrated the genetic diversity of these chickens and reinforced the socio-cultural and economic importance of native chickens in Bhutan. In addition, the PCA analysis showed that Bhutanese native chickens are important contributors to the general poultry gene pool.

\section{Acknowledgments}

This study was funded by the Thai International Development Cooperation Agency and the Research and Development Network Center for Animal Breeding (Native chicken). This work was also supported by the Higher Education Research Promotion and National Research University Project of the Office of the Higher Education Commission, Thailand, through the Food and Functional Food Research Cluster of Khon Kaen University. We thank the Bhutanese farmers, the Department of National Parks, the Wildlife and Plant Conservation (DNP) and the Department of Livestock Development, Thailand, for providing samples. The authors thank Dr. Karma Nidup (College of Natural Resources, Royal University of Bhutan, Bhutan) for his valuable comments on the manuscript. 


\section{References}

Goodwin W, Adrian L and Sibte H (2007) An Introduction to Forensic Genetics. John Wiley and Sons, London, $151 \mathrm{pp.}$

Granevitze Z, Hillel J, Chen GH, Cuc NTK, Feldam M, Eding H and Weigend S (2007) Genetic diversity within chicken populations from different continents and management histories. Anim Genet 38:576-583.

Groeneveld LF, Lenstra JA, Eding H, Toro MA, Scherf B, Pilling D, Negrini R, Finlay EK, Jianlin H, Groeneveld E, et al. (2010) Genetic diversity in farm animals - A review. Anim Genet 41(Suppl 1):6-31.

Hanotte O and Jianlin H (2005) Genetic characterization of livestock population and its use in conservation decisionmaking. The role of biotechnology. Proceedings of the International Workshop, 5-7 March 2005, Villa Gualino, Turin, Italy, pp 131-136.

Hillel J, Martien AM, Groenen AM, Boichard MT, Abraham B, Korol AB, David L, Kirzhner VM, Burke T, Barre-Dirief A, et al. (2003) Biodiversity of 52 chicken populations assessed by microsatellite typing of DNA pools. Genet Select Evol 35:533-57.

Mazzi CA, Ferro JA, Ferro MT, Savino VJM, Coelho AAD and Macari M (2003) Polymorphism analysis of the hsp70 stress gene in broiler chickens (Gallus gallus) of different breeds. Genet Mol Biol 26:275-281.

Merat P (1986) Potential usefulness of the Na (Naked neck) gene in poultry production. World's Poult Sci J 42:124-142.

Moiseyeva IG, Romanov MN, Nikiforov AA, Sevastyanova AA and Semyenova SK (2003) Evolutionary relationships of Red Junglefowl and chicken breeds. Genet Select Evol 35:403-423.

Mukesh T, Kalasi RS, Mandhan RP and Sathyakumar S (2011) Genetic diversity studies of Red Junglefowl across its distribution range in northern India. Asian J Biotechnol 3:293301.

Nassiri MTB, Hamid Z and Tavakoli S (2007) The investigation of genetic variation at microsatellite loci in Mazandran native chickens. J Poult Sci 6:675-678.

Nassiry MR, Javanmard A and Tohidi R (2009) Application of statistical procedures for analysis of genetic diversity in domestic animal populations. Am J Anim Vet Sci 4:136-141.

Nidup K and Tshering P (2007) Status of the family poultry production and HPAI in Bhutan. Proceedings of the $8^{\text {th }}$ Asian Pacific Poultry Conference of the World's Poultry Science Association, Bangkok, pp 78-83.

Nidup K, Penjor A, Dorji P, Gurung R, Arasta P and Moran C (2005) Genetic structure of the native chickens of Bhutan. SAAR J Agric 3:69-89.

Nidup K, Penjor A and Dorji P (2008) Poultry. In: Dorji TY and Tamang S (eds) Animal Genetic Resources of Bhutan. Kuensel Cooperation, Thimphu, pp 26-47.

Nei M (1978) Estimation of heterozygosity and genetic distance from a small number of individuals. Genetics 89:583-590.

Patra BN, Bais RKS, Prasad RB and Singh BP (2002) Performance of naked neck versus normally feathered colored broilers for growth, carcass traits and blood biochemical parameters in tropical climate. Asian-Australasian J Anim Sci 15:1776-1783.

Pirany N, Romanov NMN, Ganpule SP, Govindaiah D and Doddananjat P (2007) Microsatellites analysis of genetic biodiversity in India chicken populations. J Poult Sci 44:19-28.

Raymond M and Rousset F (1995) GENEPOP ver. 1.2: Population genetics software for exact tests and ecumenicism. J Hered 86:248-259.

Rosenberg NA, Burke T, Elo K, Feldman MW, Groenen MAM, Hillel J, MäkiTanila A, Tixier-Boichard M, Vignal A, Wimmers K, et al. (2001) Empirical evaluation of genetic clustering methods using multilocus genotypes from 20 chicken breeds. Genetics 159:699-713.

Rousset F (2008) Genepop'007: A complete reimplementation of the Genepop software for Windows and Linux. Mol Ecol Res 8:103-106.

Saitou N and Nei M (1987) The neighbor-joining method: A new method for reconstructing phylogenetic trees. Mol Biol Evol 4:406-425.

Semik E and Krawczyk J (2011) The state of poultry genetic resources and genetic diversity of hen populations. Ann Anim Sci 11:181-191.

SAS Statistical Analysis Software (1998) User’s Guide: ver. 6.12. SAS Institute Inc., Cary, NC.

Tadano R, Sekino M, Nishibori M and Tsudzuki M (2007) Microsatellite marker analysis for the genetic relationships among Japanese long-tailed chicken breeds. J Poult Sci 86:460-469.

Tunim S, Duangjinda M and Katavatin S (2010) Study of HSP 70 gene polymorphism in various strains of Thai native chickens. Khon Kaen Agric J 38(Supplement):71-75.

van Marle-Köster E, Hefer CA, Nel LH and Groenen MAM (2008) Genetic diversity and population structure of locally adapted South African chicken lines: Implications for conservation. S Afr J Anim Sci 38:271-281.

Weigend S and Romanov MN (2001) Current strategies for the assessment and evaluation of genetic diversity in chicken resources. World's Poult Sci J 57:275-288.

Yamamoto Y, Nishibori M, Kinoshita K, Tsunda K, Nimkawa T, Mannen H, Tshering C and Dorji T (2007) Composition of the genes controlling blood groups and morpho-genetic traits of Bhutanese native chickens and its phylogenetic study. Report Soc Res Native Livestock 24:167-178.

Yunis R and Cahaner A (1999) The effects of naked-neck (Na) and frizzle $(\mathrm{F})$ genes on growth and meat yield of broilers, and their interactions with ambient temperatures and potential growth rate. Poult Sci 78:1374-1382.

\section{Internet Resources}

FAO Domestic Animal Diversity Information System, http://dad.fao.org/ (January 13, 2011).

Associate Editor: Alexandre Rodrigues Caetano

License information: This is an open-access article distributed under the terms of the Creative Commons Attribution License, which permits unrestricted use, distribution, and reproduction in any medium, provided the original work is properly cited. 